\title{
Ocean researchers make waves in quest for funds and military data
}

Washington. Ocean scientists are planning to make a direct appeal to Congress this week for a concerted effort to obtain open access to secret ocean data of high scientific value held by the US military, and for an extra \$25 million a year to strengthen university research in their discipline.

In particular, Congress will be asked to back a National Ocean Leadership Council to coordinate ocean research across the government, a proposal that is being put to it by the Consortium for Oceanographic Research and Education (CORE).

The proposal will be put forward by CORE's president, Admiral James Watkins, a former energy secretary under President George Bush. The council would be cochaired by the top-ranking admiral of the US Navy and the administrator of the National Oceanic and Atmospheric Administration (NOAA).

A priority for the council would be to accelerate the declassification of extensive sets of magnetic and acoustic data on the world's oceans that have been gathered by the US Navy. Watkins says that the existing system for doing this is cumbersome and bureaucratic. "It's a slow system that needs aggressive reappraisal," he says.

CORE's plan is due to be put to a joint hearing of three House of Representatives' subcommittees on ocean research. Witnesses will include Admiral Jeremy Boorda, chief of naval operations, Bruce Alberts, president of the National Academy of Sciences, Neal Lane, director of the National Science Foundation (NSF), NOAA administrator James Baker, as well as Watkins.

The research subcommittee of the National Security Committee, chaired by Curt Weldon (Republican, Pennsylvania), will join with the energy and environment subcommittee of the Science Committee, chaired by Dana Rohrabacher (Republican, California), and the fisheries, wildlife and oceans subcommittee of the Resources Committee, chaired by James Saxton (Republican, New Jersey), for the hearing.

The event has been orchestrated by Weldon and his fellow-Republican Watkins as a boost to ocean research at a time of shrinking research budgets. But some researchers fear that CORE's high-profile tactics could hurt other scientific disciplines.

Some observers say that there is a thin line between speaking out for the discipline and doing so at the expense of others. "Sometimes CORE gets close to that line," says one senior ocean scientist, adding: "I always worry that disciplines that are not so

well-organized will be deemed less worthy."

Watkins declines to suggest where extra money for oceanography should come from. "That's not our responsibility," he says. "Our job is to say this is good stuff, thoroughly peer-reviewed and underfunded."

But he feels that research on the oceans has been overshadowed by other environmental sciences. "The oceans were never mentioned once at Rio," he says, referring to the Earth Summit at Rio de Janeiro in 1992. Richard Spinrad, research director at CORE, goes further, by arguing that oceanography "should not be thrown into the basket with all

the other environmental sciences".

According to the Ocean Studies Board at the National Research Council, total federal investment in ocean research has remained relatively constant at $\$ 525$ million a year (in Watkins: coordination 1995 also needs improving. lars) since

1982. More than a third of this is funded by NSF, and a further third between the Office of Naval Research and NOAA.

But CORE points out that investment in basic science by the federal government has grown from $\$ 8$ billion to $\$ 14$ billion in that period, and that oceanography's share has therefore fallen from 7 to 4 per cent.

Congressional staff say that, although ocean research has powerful friends in Congress, extra money is unlikely in the present fiscal climate. But they say that there is support for the opening-up of more Navy data. This week's hearing will consider whether legislation is needed to assist in this, and Watkins is pushing for a similar hearing in the Senate, where he has strong support from Mark Hatfield (Republican, Oregon),

chair of the Appropriations Committee.

Civilian oceanographers recently benefited from the release by the Department of Defense of data on the ocean surface, gathered by Geosat (see page 300). But ocean scientists say they could learn more about ocean floor chronology from magnetic field data gathered by military ships and aircraft, as ocean depth soundings would give a more accurate contoured map of the floor than one inferred from satellite data.

The Navy also has a quantity of data on the thickness of sediment on the ocean floor, and on water temperatures beneath the Arctic ice, which it gathered when 'playing hide and seek' with Soviet submarines.

In addition, an array of Navy listening stations known as Sosus - the Sound Surveillance System - collects data to which marine biologists long for access. According to one congressional staff member, biologists "learned more about whales in a few days than they'd learned in the previous forty years" when allowed access to Sosus during a brief test run in 1994. At that time, the Navy was considering transferring Sosus to civilian control, but has since decided to retain it for national security purposes.

The Navy's concern is not that the data themselves would be helpful to an enemy, but that the concentration of data points in unexpected parts of the world would betray US interests. Oceanographers say the data could be processed to prevent this undesired leakage of information.

CORE's proposal of a Leadership Council will not be welcomed by the Clinton administration. According to James Baker of NOAA, mechanisms for coordination already exist, through three subcommittees of the White House's National Science and Technology Council. And, says Baker, NOAA has "a direct and formal tie" with the Navy and the Air Force: senior officers of both forces work in NOAA as advisers to Baker's office.

Colin Macilwain

\section{NASA's planet search programme 'on track'}

San Antonio, Texas. The launch of a spacebased interferometer capable of detecting life around Earth-like planets should be feasible within ten years, Daniel Goldin, head of the US National Aeronautics and Space Administration (NASA), told a meeting of the American Astronomical Society in San Antonio, Texas, last week.

Goldin's vision for space science includes a 'next-generation' space telescope, and an aggressive programme to search for planets around other stars (see Nature 378, 650; 1995). While warning "I'm not making any guarantees", he said the search should be possible even with NASA's shrinking budget.

Goldin was optimistic about two nearterm projects - the Advanced X-Ray Astrophysics Facility (AXAF) and the Space Infrared Telescope Facility (SIRTF). "I will personally throw my body across the tracks if anyone interferes with SIRTF," he told the meeting.

Tony Reichhardt 